\title{
Ethidium Monoazide for DNA-Based Differentiation of Viable and Dead Bacteria by $\mathbf{5}^{\prime}$-Nuclease PCR
}

BioTechniques 34:804-813 (April 2003)

\author{
Hege Karin Nogva, Signe \\ Marie Dromtorp, Hilde \\ Nissen, and Knut Rudi \\ Norwegian Food Research \\ Institute, ÅS, Norway
}

\section{ABSTRACT}

PCR techniques have significantly improved the detection and identification of bacterial pathogens. Even so, the lack of differentiation between DNA from viable and dead cells is one of the major challenges for diagnostic DNA-based methods. Certain nucleic acid-binding dyes can selectively enter dead bacteria and subsequently be covalently linked to DNA. Ethidium monoazide (EMA) is a DNA intercalating dye that enters bacteria with damaged membranes. This dye can be covalently linked to DNA by photoactivation. Our goal was to utilize the irreversible binding of photoactivated EMA to DNA to inhibit the PCR of DNA from dead bacteria. Quantitative 5'-nuclease PCR assays were used to measure the effect of EMA. The conclusion from the experiments was that EMA covalently bound to DNA inhibited the 5'-nuclease PCR. The maximum inhibition of $P C R$ on pure DNA cross-linked with EMA gave a signal reduction of approximately $-4.5 \log$ units relative to untreated DNA. The viable/dead differentiation with the EMA method was evaluated through comparison with BacLight ${ }^{T M}$ staining (microscopic examination) and plate counts. The EMA and BacLight methods
\end{abstract}

gave corresponding results for all bacteria and conditions tested. Furthermore, we obtained a high correlation between plate counts and the EMA results for bacteria killed with ethanol, benzalkonium chloride (disinfectant), or exposure to $70^{\circ} \mathrm{C}$. However, for bacteria exposed to $100^{\circ} \mathrm{C}$, the number of viable cells recovered by plating was lower than the detection limit with the EMA method. In conclusion, the EMA method is promising for DNA-based differentiation between viable and dead bacteria.

\section{INTRODUCTION}

DNA-based methods such as PCR have been increasingly used for the rapid, sensitive, and specific detection of pathogens (1). However, there are still limitations in the usage of nucleic acid-based diagnostics. A major obstacle is the lack of differentiation between DNA from viable and dead microorganisms (2-4). The DNA molecule may remain intact even though the organism is dead (5-9). RNA has been used as a viable/dead marker due to its intrinsic instability $(3,4,10,11)$. However, accurate viable/dead measurements are difficult using RNA as a target. The gene analyzed has to be continuously expressed, and the transcript has to be relatively unstable.

Most disinfection and preservation techniques are aimed at either inactivating or removing potential pathogens. Generally, the bacteria die before the DNA is destroyed. The ability of the nucleic acids from dead cells to generate PCR signals is affected by the preservation technique, disinfection treatment, and organism $(2,12)$. It is therefore a great demand for sample preparation methods related to whether the organisms are viable or dead to fully exploit the potential of PCR in microbiological diagnostics. An aspect that has not yet been used in PCR analyses is the physical differences between viable and dead cells. This concept, however, is widely used in both microscopy and flow cytometry. Ethidium monoazide (EMA) (Molecular Probes Europe BV, Leiden, The Netherlands) has been used as a livedead stain in several of these assays (13-19). EMA is a DNA intercalating agent (20), and photolysis of EMA with visible light produces a nitrene (21) that forms stable monoadducts when bound to DNA $(22,23)$. The free EMA in solution is photolyzed simultaneously and converted to hydroxylamine (21) and is no longer capable of covalent attachment (24).

Our goal in the current study was to utilize the irreversible binding of photoactivated EMA to DNA to inhibit the PCR of DNA from dead bacteria. Quantitative 5'-nuclease PCR was used to measure the effect of EMA. The maximum inhibition of PCR on pure DNA cross-linked with EMA gave a signal reduction (EMASR) of approximately $-4.5 \log$ units relative to untreated DNA. E. coli O157:H7, Salmonella spp., and Listeria monocytogenes were 
tested as model organisms. Heat, disinfectants, and alcohol were used as killing agents. There was a high correlation between plate counts and the EMASR for the bacteria and conditions tested. The novelty of the approach is the use of an agent (EMA) that selectively modifies the DNA in dead cells so that only the DNA in viable cells can be PCR amplified.

\section{MATERIALS AND METHODS}

\section{Bacterial Strains, Media, and Cultures}

Model organisms used were $E$. coli O157:H7 NCTC 1200 (National Collection of Type Cultures, Colindale, London), E. coli O157:H7 MATFORSK (MF) strain 667, E. coli O157:H7 isolate 604 (Y. Wasteson, Veterinary Institute, Oslo, Norway), $L$. monocytogenes L028 wild-type (Institut Pasteur, Paris, France), L. monocytogenes EGDe serotype 1/2a (Institut Pasteur), L. monocytogenes MATFORSK strain 54 (L.-M. Rørvik, Norwegian College of Veterinary Medicine, Oslo, Norway), L. monocytogenes DSMZ 20600 (Deutsche Sammlung von Mikroorganismen und Zellkulturen $\mathrm{GmbH}$, Braunschweig, Germany) type strain, Salmonella sp. ATCC 13311 (ATCC, Rockville, MD, USA), and Salmonella sp. MF strain 16.

Listeria was grown in Brain Heart Infusion (BHI) media at $30^{\circ} \mathrm{C}$. E. coli and Salmonella were grown in BHI media at $37^{\circ} \mathrm{C}$. The cultures were serially diluted in peptone water. The cfu were determined by plating $0.1 \mathrm{~mL}$ of each dilution onto $\mathrm{BHI}$ agar and incubating at $30^{\circ} \mathrm{C}$ (Listeria) or $37^{\circ} \mathrm{C}$ for 1-2 days. All agars and media were from Oxoid Ltd. (Basingstoke, Hampshire, UK).

\section{Viable/Dead Staining for Microscopy}

The two-color fluorescence assay LIVE/DEAD ${ }^{\circledR}$ Bac Light $^{\mathrm{TM}}$ Bacterial Viability Kit (Molecular Probes Europe BV) was used to stain the organisms for microscopy. SYTO ${ }^{\circledR} 9$ stain (Molecular Probes Europe BV) generally labels all bacteria in a population green, while propidium iodide penetrates only bacteria with damaged membranes and labels these red (i.e., reducing the SYTO 9 stain fluorescence when both dyes are present). To compare BacLight staining and staining with EMA in combination with 46-di-amidino-2-phenyl-indol (DAPI) (stains nucleic acids), $1 \mathrm{~mL}$ of the respective samples was pelleted at $10000 \times g$ for $7 \mathrm{~min}$. The samples were stained with BacLight, following the manufacturer's instructions, incubated for $15 \mathrm{~min}$, and filtered through Osmonic Polycarbonate Filters $25 \mathrm{~mm}$ (Osmonic, Minnetonka, MN, USA), washed with peptone water, and mounted on slides.

The samples were also stained with $1 \mu \mathrm{g} / \mathrm{mL}$ EMA for $5 \mathrm{~min}$ on ice in the dark, subjected to a $650-\mathrm{W}$ halogen lamp for $1 \mathrm{~min}$, and filtered as described earlier. The EMA-stained filters were subsequently counterstained with $10 \mu \mathrm{g} / \mathrm{mL}$ DAPI.

\section{Heat and Disinfection Treatments}

Overnight stationary phase cultures were used in the experiments. The number of bacteria was determined by plate counting, and samples from the same culture were used in each parallel experiment (i.e., the amount of cfu was equal in each experimental series). The cultures were either heat treated for 5 $\min \left(72^{\circ} \mathrm{C}\right.$ or $\left.100^{\circ} \mathrm{C}\right)$ or pelleted at $5000-6000 \times g$ for $7 \mathrm{~min}$ at $4^{\circ} \mathrm{C}$ and resuspended in the killing agents $(96 \%$ ethanol, $70 \%$ isopropanol, or $500 \mathrm{ppm}$ benzalkonium chloride) and incubated at $20^{\circ} \mathrm{C}$ for $5-30 \mathrm{~min}$. Then the samples were pelleted and resuspended in equal volumes of BHI media as described earlier.

\section{EMA Cross-Linking}

EMA bromide (phenanthridium, 3amino-8-azido-5-ethyl-6-phenyl bromide) was purchased from Molecular Probes Europe BV. Five micrograms of solid were dissolved in $0.5 \mathrm{~mL}$ water in dark microcentrifuge tubes and further diluted. The solutions were stored at $-20^{\circ} \mathrm{C}$ and kept on ice when used. EMA is potentially carcinogenic and should be treated according to the manufacturer's safety instructions. The light source was an OSRAM SLG 1000 (Osram AS, Drammen, Norway) with a $650-\mathrm{W}$ halogen light bulb, which was placed $20 \mathrm{~cm}$ from the sample tubes. The microcentrifuge tubes were placed on ice to minimize elevated temperature in the samples.

\section{DNA Isolations}

DNA was isolated using PrepMan ${ }^{\mathrm{TM}}$ Sample Preparation Reagent (Applied Biosystems, Foster City, CA, USA), according to the manufacturer's protocol. The samples $(0.10-0.15 \mathrm{~mL})$ were added to $0.2 \mathrm{~mL}$ PrepMan extraction reagent and incubated at $56^{\circ} \mathrm{C}$ for 30 min. The samples were then vortex mixed for $10 \mathrm{~s}$, boiled for $8 \mathrm{~min}$, and centrifuged at $16000 \times g$ for $5 \mathrm{~min}$. The supernatants were diluted and subjected to 5 '-nuclease PCR.

\section{5'-Nuclease PCR Assay}

Primers and probes for $E$. coli O157:H7 were constructed for the attaching and effacing gene intimin (eae). The assay constituted forward primer 5'-CTGAATTTGATACCTTAAGTGCAGC-3', reverse primer 5'-AGGCACGCCTAAACCTATAGCT- ${ }^{\prime}$, and probe 5'-TCTCCTTGCTCATCTTTAGGATAAATTCTTTCACA- $3^{\prime}$. Primers and probes for the detection and quantification of L. monocytogenes have been previously described (25). Salmonella was quantified using the TaqMan ${ }^{\circledR} \mathrm{Sal}$ monella PCR Amplification/Detection Kit (Applied Biosystems) (26).

The 5'-nuclease PCR on DNA from E. coli O157:H7, Salmonella, and L. monocytogenes was carried out as previously described $(25,27)$. PCR samples and controls were prepared in triplicate. PCR products were detected directly by monitoring the increase in fluorescence from the dye-labeledspecific DNA probes. The reporter dye, carboxyfluorescein (FAM) was covalently linked to the $5^{\prime}$ end of the oligonucleotides. The fluorescence of the reporter dye was then quenched by 6-carboxy-N, N, N', N'-tetramethylrhodamine (TAMRA) located at the $3^{\prime}$ ends. The reporter signal was normalized to the emission of an internal reference dye (ROX-6-carboxy-X-rhodamine). The fluorescence signal was 


\section{Research Report}

Table 1. Effect of Light Exposure and EMA Concentration on DNA Inactivation

\begin{tabular}{|c|c|c|c|c|c|c|}
\hline \multirow[b]{2}{*}{ EMA $(\mu \mathrm{g} / \mathrm{mL})$} & \multicolumn{6}{|c|}{ Light Exposurea } \\
\hline & $5 \mathrm{~s}$ & $15 \mathrm{~s}$ & $30 \mathrm{~s}$ & $45 \mathrm{~s}$ & $1 \mathrm{~min}$ & $3 \mathrm{~min}$ \\
\hline 10 & $-3.13 \pm 0.18$ & $-3.38 \pm 0.20$ & $-3.73 \pm 0.12$ & $-3.85 \pm 0.13$ & $-3.39 \pm 0.18$ & $-2.64 \pm 0.13$ \\
\hline 100 & $-2.06 \pm 0.08$ & $-3.60 \pm 0.34$ & $-4.61 \pm 0.06$ & $-4.16 \pm 0.30$ & $-3.85 \pm 0.45$ & $-4.61 \pm 0.06$ \\
\hline
\end{tabular}

aEMA was cross-linked to DNA for the given time periods. Fractions $\left(\log _{10}\right)$ of the treated DNA giving PCR signals relative to untreated DNA are shown. Standard deviations from three replicates are included.

Table 2. Effect of Photolysis of EMA before Cross-Linking to DNA

\begin{tabular}{|c|c|c|c|c|c|c|}
\hline \multirow[b]{2}{*}{ EMA $(\mu \mathrm{g} / \mathrm{mL})$} & \multicolumn{6}{|c|}{ EMA Photolysisa } \\
\hline & $5 \mathrm{~s}$ & $15 \mathrm{~s}$ & $30 \mathrm{~s}$ & $45 \mathrm{~s}$ & $1 \mathrm{~min}$ & $3 \mathrm{~min}$ \\
\hline 10 & $-1.36 \pm 0.27$ & $-0.29 \pm 0.42$ & $-0.17 \pm 0.26$ & $-0.20 \pm 0.47$ & $-0.02 \pm 0.15$ & $-0.04 \pm 0.07$ \\
\hline 100 & $-4.23 \pm 0.31$ & $-0.89 \pm 0.04$ & $-0.53 \pm 0.05$ & $-0.67 \pm 0.12$ & $-0.61 \pm 0.09$ & $-1.24 \pm 0.02$ \\
\hline
\end{tabular}

aEMA was photolysed for the given time periods before cross-linking to DNA. Fractions $\left(\log _{10}\right)$ of the treated DNA giving PCR signals relative to untreated DNA are shown. Standard deviations from three replicates are included.

plotted as $\Delta \mathrm{R}_{\mathrm{n}}$, which was the normalized reporter signal minus background, against the number of cycles. The threshold cycles $\left(\mathrm{C}_{\mathrm{T}}\right)$ was determined for each amplification plot by setting a fixed threshold $\left(\Delta R_{n} 0.03\right)$ above the baseline (background). Different amplifications could then be compared by their respective $\mathrm{C}_{\mathrm{T}} \mathrm{S}$ since calculated threshold values are proportional to the number of target copies present in the sample (28). The $\mathrm{C}_{\mathrm{T}}$ values were plotted against log input cfu, and the corresponding standard curves were used to estimate slopes and square regression coefficients $\left(R^{2}\right)$ by linear regression to evaluate the quantitative properties of the assays $(28,29)$. The efficiencies (E) were calculated using the equation $\mathrm{E}=10^{-1 / \mathrm{s}}-1$, where $\mathrm{s}$ is the slope of the regression curve (30). $\mathrm{C}_{\mathrm{T}}$ values for the non-EMA-treated samples were subtracted from the $\mathrm{C}_{\mathrm{T}}$ values for the corresponding EMA-treated samples. This gave $\Delta \mathrm{C}_{\mathrm{T}}$ values for the effect of the EMA treatments, independent of the amount of template added. Finally, the $\Delta \mathrm{C}_{\mathrm{T}} \mathrm{S}$ were divided by the slope of the regression curve to calculate the $\log _{10}$ of the EMASR. EMASR represents an approximation of the DNA fraction in the EMA-treated samples that than be PCR amplified.

\section{Correlation Analyses}

The Pearson correlation coefficient was used to measure the degree of the linear relationship between the plate counts and the 5-nuclease PCR data. The correlation coefficient was calculated with the following formula for the two variables $\mathrm{x}$ and $\mathrm{y} ; \mathrm{r}=\Sigma\left(\mathrm{x}-\mathrm{m}_{\mathrm{x}}\right)(\mathrm{y}-$ $\left.m_{y}\right) /(n-1) s_{x} s_{y}$, where $m_{x}$ and $s_{x}$ are the sample mean and the standard deviation for the first variable, and $\mathrm{m}_{\mathrm{y}}$ and $\mathrm{s}_{\mathrm{y}}$ are the sample mean and standard deviation for the second variable.

\section{RESULTS}

\section{Evaluation of the Quantification Assays}

The reproducibility of the PrepMan Sample Preparation Reagent and the $5^{\prime}$ nuclease primer and probe systems were tested using E. coli O157:H7 NCTC 1200, L. monocytogenes EGDe, and Salmonella sp ATCC 13311. Dilution series were made from both cells before DNA purification and from pure DNA. Slopes of the standard curves and their corresponding amplification efficiencies, together with the square regression coefficients $\left(\mathrm{R}^{2}\right)$, were then determined. The slopes of the regres- sion curves in all cases were between -3.3 and -3.4. All three detection systems gave amplification efficiencies in the range from 0.98 to 1.0 and an $\mathrm{R}^{2}$ from 0.995 to 0.999 . These values were subsequently used in quantifying the effect of the EMA treatment.

\section{Influence of the EMA Fluorescence on the $5^{\prime}$-Nuclease PCR Assay}

The influence of EMA fluorescence on the $5^{\prime}$-nuclease PCR assay was examined. The raw spectra and the multicomponent spectra were determined. The spectra were not affected by EMA content below $200 \mu \mathrm{g} / \mathrm{mL}$. Higher contents gave a proportional decrease in the fluorescence intensity of the background reporter signal (FAM) (data not shown).

\section{Optimization and Evaluation of the EMA/DNA Cross-Linking Process}

EMA was cross-linked to pure DNA using different irradiation times and EMA concentrations. The highest PCR inhibition was obtained using DNA cross-linked with $100 \mu \mathrm{g} / \mathrm{mL}$ EMA and irradiation for more than $30 \mathrm{~s}$. This resulted in an EMASR in the range from -3.9 to $-4.6 \operatorname{logs}$ (Table 1 ).

To control the efficiency of photoly- 


\section{Research Report}

Table 3. Effect of EMA Concentration and Exposure Time for Differentiation between Viable and Isopropanol-Killed $E$. coli $0157: H 7$

\begin{tabular}{|c|c|c|c|c|c|}
\hline \multirow{2}{*}{$\begin{array}{l}\text { EMA } \\
(\mu \mathrm{g} / \mathrm{mL})\end{array}$} & \multicolumn{5}{|c|}{ EMA Exposure } \\
\hline & $5 \mathrm{~s}$ & $30 \mathrm{~s}$ & $1 \mathrm{~min}$ & $5 \mathrm{~min}$ & $10 \mathrm{~min}$ \\
\hline \multicolumn{6}{|l|}{ Viable } \\
\hline 10 & $-0 \pm 0.11$ & $-0.20 \pm 0.05$ & $-0.35 \pm 0.04$ & $-0.39 \pm 0.03$ & $-0.31 \pm 0.06$ \\
\hline 100 & $-0.20 \pm 0.05$ & $-0.26 \pm 0.06$ & $-0.37 \pm 0.04$ & $-0.24 \pm 0.03$ & $-0.25 \pm 0.03$ \\
\hline \multicolumn{6}{|l|}{ Dead } \\
\hline 10 & $-1.25 \pm 0.06$ & $-1.22 \pm 0.03$ & $-1.30 \pm 0.06$ & $-1.12 \pm 0.04$ & $-1.44 \pm 0.08$ \\
\hline 100 & $-1.70 \pm 0.03$ & $-1.62 \pm 0.07$ & $-2.03 \pm 0.07$ & $-2.31 \pm 0.07$ & $-2.44 \pm 0.18$ \\
\hline $\begin{array}{l}\text { aThe cells } \\
\text { cross-lin } \\
\text { signals } r \\
\text { replicate }\end{array}$ & $\begin{array}{l}\text { ere exposed } \\
\text { g with light fo } \\
\text { tive to untrea } \\
\text { ire included. }\end{array}$ & $\begin{array}{l}\text { to EMA for the } \\
1 \text { min. Fracti } \\
\text { ited DNA are }\end{array}$ & $\begin{array}{l}\text { e given time } p \\
\text { ions }\left(\log _{10}\right) \text { of } \\
\text { shown. Stand }\end{array}$ & $\begin{array}{l}\text { iods in the da } \\
\text { he treated DN } \\
\text { d deviations } f\end{array}$ & $\begin{array}{l}\text { rk before } \\
\text { A giving PCR } \\
\text { rom three }\end{array}$ \\
\hline
\end{tabular}

sis (i.e., the inactivation of free EMA in solution), EMA was irradiated without DNA, as described earlier. The maximum effect was obtained for irradiation between $30 \mathrm{~s}$ and $1 \mathrm{~min}$ (Table 2). The EMASRs were approximately $-0.5 \operatorname{logs}$ for $100 \mu \mathrm{g} / \mathrm{mL}$ EMA and $-0.2 \operatorname{logs}$ for $10 \mu \mathrm{g} / \mathrm{mL}$ EMA. A high concentration $(333 \mu \mathrm{g} / \mathrm{mL})$ of photolysed EMA inhibited the PCR regardless of irradiation time (data not shown).

Finally, we tested whether DNA cross-linked with EMA had an effect on the detection of native DNA. This

was done by subjecting native DNA, DNA cross-linked with EMA, and a mixture of the two to $5^{\prime}$-nuclease PCR. There was no influence from the EMAcross-linked DNA on the detection of native DNA (data not shown).

\section{Evaluation of the EMA Assay Using Isopropanol-Killed Cells}

The bacteria were either untreated or killed with $70 \%$ isopropanol (see Materials and Methods). E. coli O157:H7 NTNC 1200 was used as a model to op-

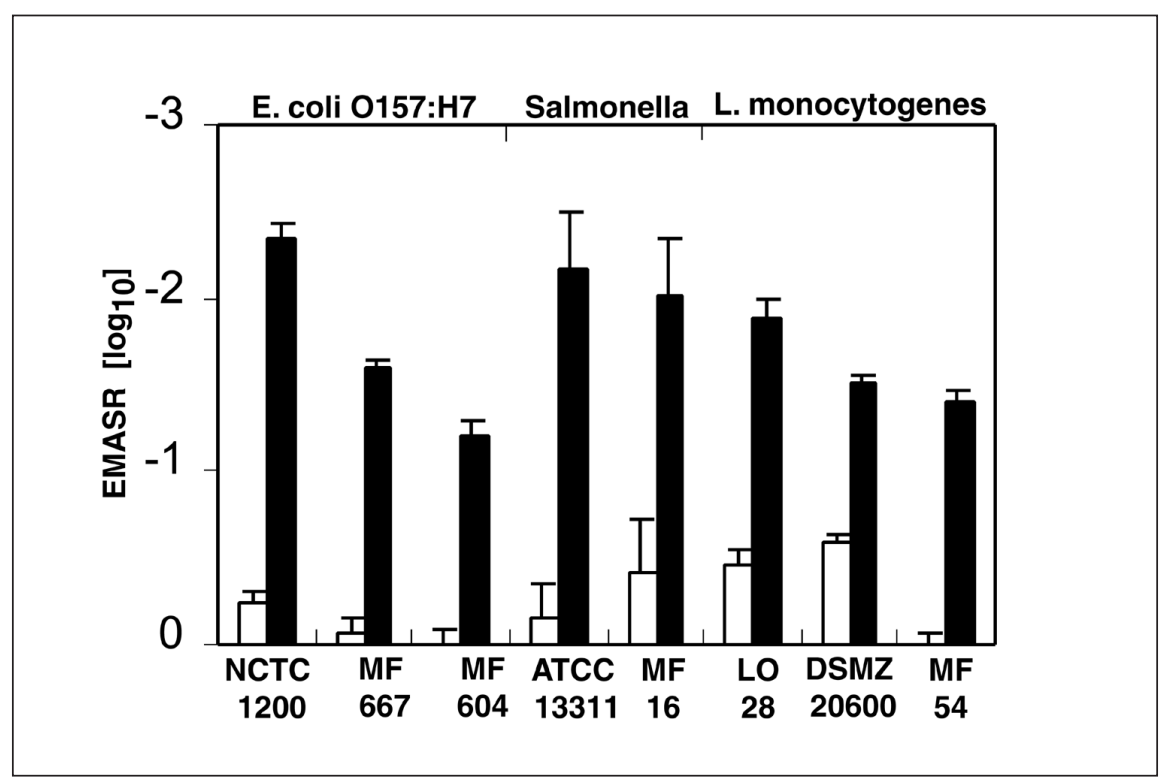

Figure 1. Evaluation of the EMA assay on viable (white bars) or isopropanol-killed bacteria (black bars). The EMASR is shown (see Materials and Methods for definition). The cells were exposed to $70 \%$ isopropanol for $30 \mathrm{~min}$. The error bars are the standard deviations of three replicates. timize the exposure time and concentration of EMA (Table 3). There was no detectable difference in the PCR signals from viable $E$. coli $\mathrm{O} 157: \mathrm{H} 7$ with 10 or $100 \mu \mathrm{g} / \mathrm{mL}$ EMA added for incubation up to 10 min. Incubation with $100 \mu \mathrm{g} / \mathrm{mL}$ EMA for $5 \mathrm{~min}$ or more gave the best inactivation with a EMASR of approximately -2.5 logs for the killed cells.

A set of three E. coli $\mathrm{O} 157: \mathrm{H} 7$ strains, two Salmonella strains, and three L. monocytogenes strains were tested using a standardized protocol with $100 \mu \mathrm{g} / \mathrm{mL}$ EMA, incubation in the dark for 5 min, with subsequent irradiation for $1 \mathrm{~min}$. The bacteria were killed as described earlier. All the strains tested gave a good differentiation between the viable and dead bacteria (Figure 1). However, there was, a relatively high amount of dead bacteria in some of the overnight cultures, resulting in inhibition for the corresponding viable controls (determined by BacLight staining).

\section{Comparison of the EMA Assay and Plate Counts Using Heat- or Disinfectant-Treated Cells}

We tested heat, ethanol, or benzalkonium chloride as disinfecting agents. The Salmonella strain was relatively resistant to the conditions tested, while the L. monocytogenes strain was sensitive to heat and benzalkonium chloride (Figure 2). The correlation between the $\log \mathrm{cfu}$ and the EMASR for the conditions tested was determined (see Materials and Methods). A Pearson correlation of 0.919 for all conditions (except $100^{\circ} \mathrm{C}$ ) indicated a high linear relation between $\log \mathrm{cfu}$ and the DNA signal. The more than $-7 \log$ reduction in cfu for bacteria killed at $100^{\circ} \mathrm{C}$ was probably below the detection limit for the EMA assay. The maximum differentiation between the EMA-stained DNA and DNA without EMA is an EMASR of approximately $-4.5 \log$ (see Table 1).

\section{Comparison of EMA and BacLight Staining Using Microscopic Examination}

There was a good correspondence between EMA staining and the Bac- 


\section{Research Report}

Light system, using microscopic examinations for the bacteria and killing agents tested here (empirical data). Furthermore, there was a clear difference at the cell level between bacteria stained with EMA (potentially dead) and the bacteria that did not stain (potentially viable). Figure 3 illustrates the correspondence between EMA and BacLight staining for Salmonella typhimurium. There are dead cells present in the "viable" population of $S$. typhimurium, which was stained with EMA (Figure 3C). This coincides with results of staining with $\mathrm{BacLight}$ (Figure $3 \mathrm{E}$ ) (live cells give green fluorescence, and dead cells give red/brown fluorescence). Nearly all the killed cells were stained with EMA (Figure 3D). These cells were also stained as dead using BacLight (Figure 3F). The reason for presenting qualitative BacLight data is that we found it difficult to extract quantitative information from microscope examinations.

\section{DISCUSSION}

\section{EMA Cross-Linking on Pure DNA}

The photolysis of EMA was shown to be a first order reaction with respect to time (31), and the half-life was calculated as $\tau=2.71 \times 10^{2} \mathrm{~s}$ when daylight light bulbs were used (32). Cantrell et al. (33) found significant differences in the rates of photolysis that resulted from variations in light intensity. However, the final extent of adduct formation on prolonged irradiation was identical. Our experience is that a maximum inhibition of the PCR signal from -3.9 to $-4.6 \operatorname{logs}$ was obtained after $15-30 \mathrm{~s}$ of irradiation.

Unbound EMA molecules at the time of photoactivation will react with solvent and be "inactivated." These molecules are no longer capable of covalent attachment $(32,34,35)$. With our light source, maximum inactivation was obtained between $30 \mathrm{~s}$ and $1 \mathrm{~min}$. A light exposure period of 1 min was therefore chosen for our standardized assay. The reason was both to ensure maximum cross-linking to DNA and to inactivate the free EMA (so it will no longer react with DNA after lysis of the bacteria).

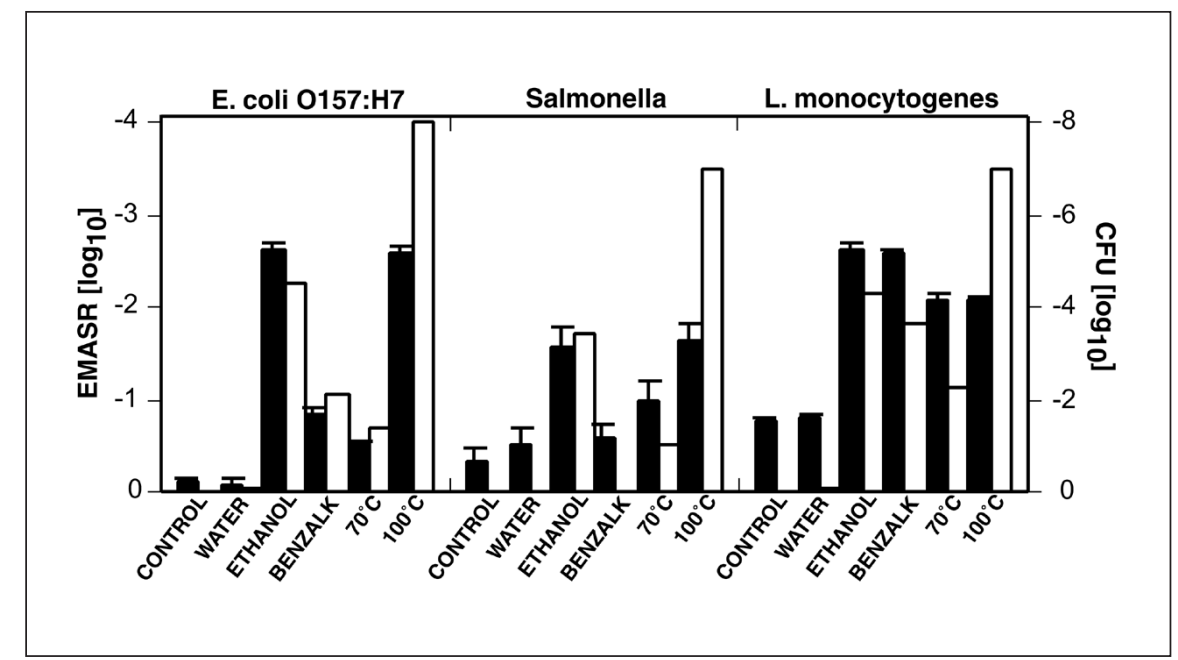

Figure 2. Comparison of EMA assay (black bars) and cfu (white bars) for bacteria treated for 5 min under different conditions. The EMASR is shown (see Materials and Methods for definition). The error bars are the standard deviations of three replicates. Values are shown for the cfu counts after treatment relative to the counts before treatment. For $100^{\circ} \mathrm{C}$, no viable cells were recovered in a $100-\mu \mathrm{L}$ volume for Salmonella or L. monocytogenes. The bars represent the detection limits. The detection limit represents that less than one bacterium can regain the growth of the bacteria in the $100 \mu \mathrm{L}$ that were tested. The strains used are E. coli MF 667, Salmonella sp. ATCC 13311, and L. monocytogenes DSMZ 20600. BENZALK, benzalkonium chloride.

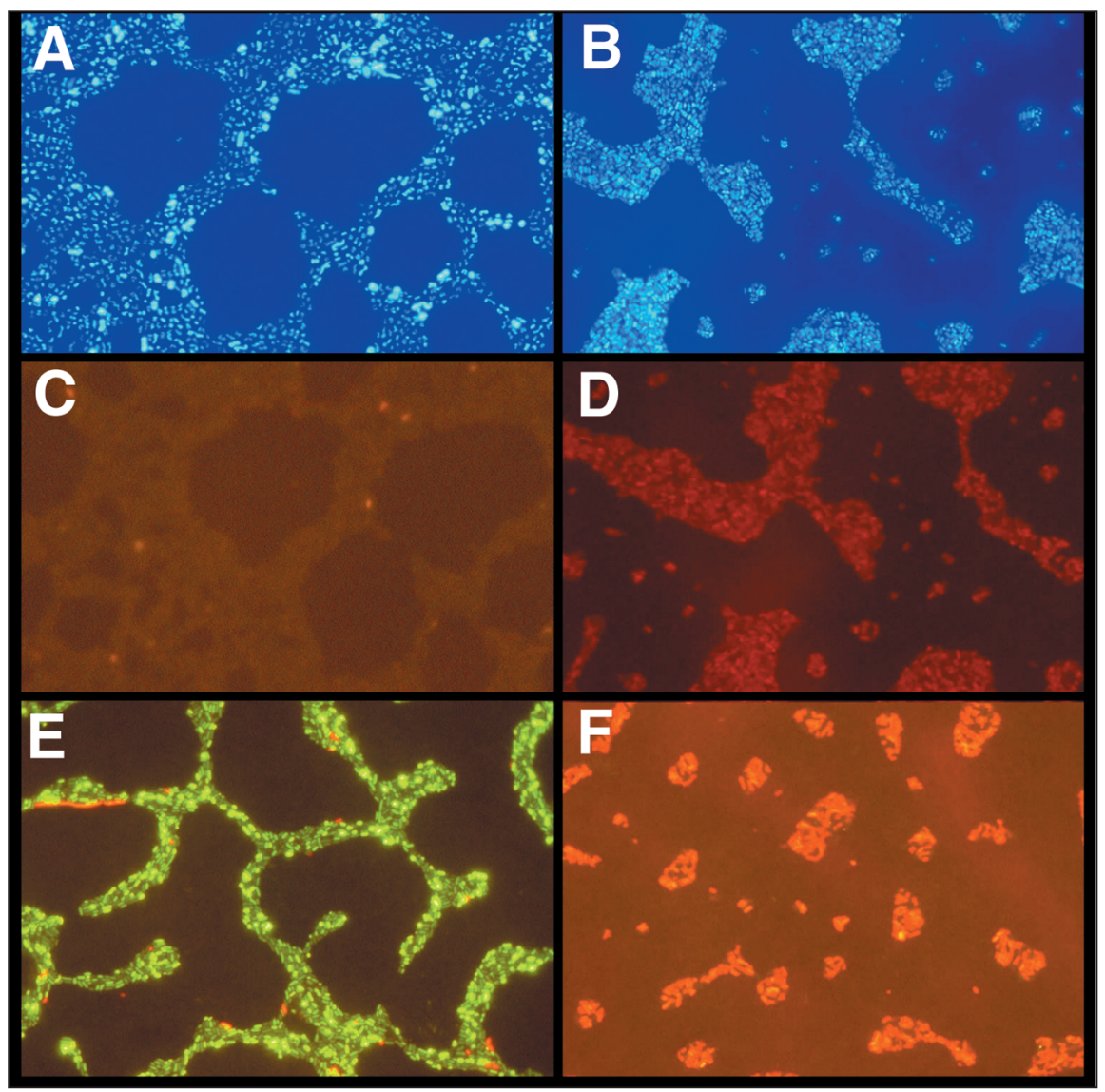

Figure 3. Epifluorescence microscopy of cells of $\boldsymbol{S}$. typhimurium. Live cells (overnight culture suspended in peptone water) stained with DAPI (A), EMA (C), and BacLight (E). Killed cells (treated with isopropanol) stained with DAPI (B), EMA (D), and BacLight (F). 


\section{Research Report}

\section{Optimization of the EMA Viable/Dead Assay on Bacteria}

A study by Yielding et al. (36) suggested that EMA and Salmonella spp. cells reach equilibrium after 3-4 min. This is in accordance with our observations that maximum differentiation between viable and dead bacteria was obtained after a 5-min exposure to EMA in the dark before cross-linking. One hundred micrograms per milliliter gave a better discrimination between viable and dead bacteria than $10 \mu \mathrm{g} / \mathrm{mL}$ EMA (see Table 3). We standardized our viable/dead assay using an EMA concentration of $100 \mu \mathrm{g} / \mathrm{mL}$, with incubation in the dark for $5 \mathrm{~min}$, and light exposure as described earlier. It is important with an EMA exposure that is sufficient to enable EMA entry into dead cells while the viable cells remain unstained since the viable/dead measurements are based on the EMASR between stained and unstained DNA.

Generally, there were slightly lower PCR signals for the viable controls treated with EMA than for the viable cells with no EMA added. The cells were from overnight cultures that had reached the stationary phase. DNA from dead cells at the time of sample collection would also be stained with EMA, contributing to the lower PCR signal from the EMA-treated viable controls than from the non-EMA-treated controls. The BacLight results confirmed the presence of dead cells in the overnight cultures with reduced signal after EMA treatment.

\section{Evaluation of the EMA Viable/Dead Assay}

Four physiological states are identified in the range from viable to dead bacteria. These states are reproductively viable, metabolically active, intact, and permeabilized dead cells (reviewed in 15). The permeation of bacteria by dyes is complex because of the structure of the bacterial cell wall and because the marked differences in the efflux pumps in the different species of bacteria (37). In the Gram-negative bacterial wall, the complex structure of the outer membrane represents the major permeability barrier, while the corresponding barrier in the Gram-positive bacteria is the peptidoglycan layer.

All viable/dead measurements have certain inherent limitations or artifacts. As described earlier, viable/dead dyes may not strictly correlate with cell viability. On the other hand, viable/dead measurements based on cell growth require that the bacteria regain growth under the conditions tested. Viable but starved or stressed bacteria may not be recovered, resulting in an underestimation in the presence of the viable bacteria $(24,38)$. The number of viable cells estimated by plating may also be biased due to aggregation of the bacteria (39).

We tested conditions in our study that did not kill all the bacteria present in the samples. Sub-lethally damaged cells should thus be expected. There was a good linear correlation between the $\log$ cfu and the log of the DNA signals obtained with the EMA method for the controls and bacteria exposed to water, ethanol, benzalkonium chloride, or heat at $70^{\circ} \mathrm{C}$ (see Figure 2). However, the two subpopulations of cells (cells that stain with EMA, and cells that can recover growth) are not necessarily the same. The correlation could be that the log differences between these populations are linear for the conditions tested. The recoverable cells probably underestimate the number of viable cells since the sub-lethally injured cells may not regain growth. For the boiled samples, the reduction in cfu was lower than the EMASR. This could be due to the presence of viable bacteria that cannot be recovered on the media used, the number of viable cells being below the detection limit for the EMA method, or both.

\section{Potential for Analyses of Mixed Populations}

None of the current viable/dead staining-based measurements are suited for analyzing different bacteria in mixed populations (13). This is a serious limitation with these methods. However, with the EMA method, we should be able to analyze mixed populations. All the bacteria in the populations are stained as either viable or dead. It should be possible to individually measure the EMASRs for the different bacteria in the population with PCR. Ultimately, the EMA method may help us to better understand the interaction among the approximately $99 \%$ of the bacteria in the environment that we are unable to grow in culture (40).

\section{ACKNOWLEDGMENTS}

We are very grateful to Philippe Glaser (Institute Pasteur), who provided the L. monocytogenes EGDe strain, Pascale Cossart (Institute Pasteur), who provided the L. monocytogenes L028 strain, Liv-Marit Rørvik (Department of Pharmacology, Microbiology and Food hygiene, Norwegian College of Veterinary Medicine, Oslo, Norway), who provided the L. monocytogenes isolate 54, and Yngvild Wasteson (Veterinary Institute, Oslo, Norway), who provided the E. coli $\mathrm{O} 157: \mathrm{H} 7$ strains. We appreciated the advice from Lars Melin, formerly at Applied Biosystems Sweden, when designing the primers and the probe of E. coli 0157:H7. This 
work was financed by the Research Levy on certain agricultural products and grant no. 139782/30 to Prior AS (Oslo, Norway) from the Norwegian Research Council.

\section{REFERENCES}

1.Olsen J.E., S. Aabo, W. Hill, S. Notermans, K. Wernars, P.E. Granum, T. Popovic, H. N. Rasmussen, and O. Olsvik. 1995. Probes and polymerase chain reaction of food-borne bacterial pathogens. Int. J. Food Microbiol. 28:1-78.

2.Herman, L. 1997. Detection of viable and dead Listeria monocytogenes by PCR. Food Microbiology 14:103-110.

3.McKillip, J.L., L.A. Jaykus, and M. Drake 1998. rRNA stability in heat-killed and UV irradiated enterotoxigenic Staphylococcus aureus and Escherichia coli O157:H7. Appl. Environ. Microbiol. 64:4264-4268.

4.Sheridan, G.E., C.I. Masters, J.A. Shallcross, and B.M. MacKey. 1998. Detection of mRNA by reverse transcription-PCR as an indicator of viability in Escherichia coli cells. Appl. Environ. Microbiol. 64:1313-1318.

5.Blaser, M.J., P.F. Smith, W.-L. Wang, and J.C. Hoff. 1986. Inactivation of Campylobacter jejuni by chlorine and monochlorine. Appl. Environ. Microbiol. 51:307-311.

6.Butler, R.C., V. Lund, and D.A. Carlson. 1987. Susceptibility of Campylobacter jejuni and Yersinia enterocolitica to UV radiation. Appl. Environ. Microbiol. 53:375-378.

7.Dupray, E., M.P. Caprais, and P. Fach. 1997. Salmonella DNA persistence in natural seawaters using PCR analysis. J. Appl. Microbiol. 82:507-510.

8.Josephson, K.L., C.P. Gerba, and I.L. Pepper. 1993. Polymerase chain reaction detection of nonviable bacterial pathogens. Appl. Environ. Microbiol. 59:3513-3515.

9.Masters, C.L., J.A. Shallcross, and B.M. Mackey. 1994. Effect of stress treatments on the detection of Listeria monocytogenes and enterotoxigenic Escherichia coli by the polymerase chain reaction. J. Appl. Bacteriol. 77:73-79.

10.McKillip, J.L., L.A. Jaykus, and M. Drake. 1999. Nucleic acid persistence in heat-killed Escherichia coli $\mathrm{O} 157: \mathrm{H} 7$ from contaminated skim milk. J. Food Prot. 62:839-844.

11.Norton, D.-M. and C.A. Batt. 1999. Detection of viable Listeria monocytogenes with a 5 ' nuclease PCR assay. Appl. Environ. Microbiol. 65:2122-2127.

12.Rossen, L., P. Norskov, K. Holmstrom, and O.F. Rasmussen. 1992. Inhibition of PCR by components of food samples, microbial diagnostic assays and DNA-extraction solutions. Int. J. Food Microbiol. 17:37-45.

13.Breeuwer, P. and T. Abee. 2000. Assessment of viability of microorganisms employing fluorescence techniques. Int. J. Food Microbiol. 55:193-200

14.Lebaron, P., N. Parthuisot, and P. Catala. 1998. Comparison of blue nucleic acid dyes for flow cytometric enumeration of bacteria in aquatic systems. Appl. Environ. Microbiol. 64:1725-730.

15.Nebe-von Caron, G., P. Stephens, and R.A. Badley. 1998. Assessment of bacterial viability status by flow cytometry and single cell sorting. J. Appl. Microbiol. 84:988-998.

16.O'Brien, M.C. and W.E. Bolton. 1995. Comparison of cell viability probes compatible with fixation and permeabilization for combined surface and intracellular staining in flow cytometry. Cytometry 19:243-255.

17.Porter, J., D. Deere, M. Hardman, C. Edwards, and R. Pickup. 1997. Go with the flow-use of flow cytometry in environmental microbiology. FEMS Microbiol. Ecol. 24:93-101.

18.Riedy, M.C., K.A. Muirhead, C.P. Jensen, and C.C. Stewart. 1991. Use of a photolabeling technique to identify nonviable cells in fixed homologous or heterologous cell populations. Cytometry 12:133-139.

19.Walberg, M., P. Gaustad, and H.B. Steen. 1999. Uptake kinetics of nucleic acid targeting dyes in S. aureus, E. faecalis and B. cereus: a flow cytometric study. J. Microbiol. Methods 35:167-176.

20.Waring, M.J. 1965. Complex formation between ethidium bromide and nucleic acids. J. Mol. Biol. 13:269-282.

21.DeTraglia M.C., J.S. Brand, and A.M. Tometski. 1978. Characterization of azidobenzamidines as photoaffinity labeling for trypsin. J. Biol. Chem. 253:1846.

22.Coffman, G.L., J.W. Gaubatz, K.L. Yielding, and L.W. Yielding. 1982. Demonstration of specific high affinity binding sites in plasmid DNA by photoaffinity labeling with ethidium analog. J. Biol. Chem. 257:1320513297.

23.Hixon, S.C., W.E. White, and K.L. Yielding. 1975. Selective covalent binding of an ethidium analog to mitochondrial DNA with production of petite mutants in yeast by photoaffinity labeling. J. Mol. Biol. 92:319-329.

24.Kell, D.B., A.S. Kaprelyants, D.H. Weichart, C.R. Harwood, and M.R. Barer. 1998. Viability and activity in readily culturable bacteria: a review and discussion of the practical issues. Antonie Van Leeuwenhoek 73:169-187.

25.Nogva, H.K., K. Rudi, K. Naterstad, A. Holck, and D. Lillehaug. 2000. Application of 5 -nuclease PCR for quantitative detection of Listeria monocytogenes in pure cultures, water, skim milk, and unpasteurized milk. Appl. Environ. Microbiol. 66:4266-4271.

26.Nogva, H.K. and D. Lillehaug. 1999. Detection and quantification of Salmonella in pure cultures using 5 '-nuclease polymerase chain reaction. Int. J. Food Micobiol. 51:191-196.

27.Nogva, H.K., A. Bergh, A. Holck, and K. Rudi. 2000. Application of the $5^{\prime}$-nuclease PCR assay in evaluation and development of methods for quantitative detection of Campylobacter jejuni. Appl. Environ. Microbiol. 66:4029-4036.

28.Heid, C.A., J. Stevens, K.J. Livak, and P.M. Williams. 1996. Real time quantitative PCR. Genome Res. 6:986-994.

29.Applied Biosystems. 1997. User bulletin 2; ABI PRISM 7700 Sequence Detection System. Applied Biosystems, Foster City, CA.
30.Klein, D., P. Janda, R. Steinborn, M. Müller, B. Salmons, and W.H. Günzburg. 1999. Proviral load determination of different feline immunodeficiency virus isolates using real-time polymerase chain reaction: Influence of mismatches on quantification. Electrophoresis 20:291-299.

31.Garland, F., D.E. Graves, L.W. Yielding, and H.C. Cheung. 1981. Comparative studies of ethidium bromide and its photoreactive analogous to nucleic acids by fluorescence and rapid kinetics. Biochemistry 19:32213226.

32.Graves, D.E., C.L. Watkins, and K.L. Yielding. 1981. Ethidium bromide and its photoreactive analogues: spectroscopic analysis of deoxyribonucleic acid binding properties. Biochemistry 20:1887-1892.

33.Cantrell, C.E., K.L. Yielding, and K.M. Pruitt. 1979. Efficiency of photolytic binding of ethidium monoazide to nucleic acids and synthetic polynucleotides. Mol. Pharmacol. 15:322-330.

34.Cantrell, C.E. and K.L. Yielding. 1981 Binding of ethidium monoazide to the chromatin in human lymphocytes. Biochim. Biophys. Acta 609:173-179.

35.Garland, F., D.E. Graves, L.W. Yielding, and H.C. Cheung. 1980. Comparative studies of the binding of ethidium bromide and its photoreactive analogous to nucleic acids by fluorescence and rapid kinetics. Biochemistry 19:3221-3226.

36.Yielding, L.W., B.R. Brown, D.E. Graves, and K.L. Yielding. 1979. Ethidium bromide enhancement of frameshift mutagenesis caused by photoactivatable ethidium analogs. Mut. Res. 63:225-232.

37.Migley, M. 1986. The phosphonium ion efflux system of Escherichia coli: relationship to the ethidium efflux system and energetic studies. J. Gen. Microbiol, 132:3187-3193.

38.Novak, J.S. and V.K. Juena. 2001. Detection of heat injury in Listeria monocytogenes Scott A. J. Food Prot. 64:1739-1743.

39.Auty, M.A, G.E Gardiner, S.J. McBrearty, E.O. O'Sullivan, D.M. Mulvihill, J.K. Collins, G.F. Fitzgerald, C. Stanton, et al. 2001. Direct in situ viability assassment of bacteria in probiotic dairy products using viability staining in conjunction with confocal scanning laser microscopy. Appl. Environ. Microbiol. 67:420-425.

40.Pace, N.R. 1997. A molecular view of microbial diversity and the biosphere. Science 276:734-40.

Received 6 December 2002; accepted 21 January 2003.

Address correspondence to:

Dr. Knut Rudi

MATFORSK

Osloveien 1, N-1430 AS, Norway

e-mail:knut.rudi@matforsk.no 